\title{
APRESENTAÇÃO DO NÚMERO
}

Aparecido Rossi

Claudio Zanini

Marcio Markendorf

Para este número da Abusões, o tema proposto para abordagens teóricas foi o modo como a produção audiovisual consolida suas visões do gótico, do insólito e do fantástico. O termo 'visão' aqui empregado carrega intencionalmente uma característica plurissignificativa provocadora, visto que a) remete à natureza dramática do audiovisual e sua natureza mista, a de arte espacial e temporal; b) explora o modo como a arte ficcional constitui uma visão da realidade, abordagem despreocupada com a tradição do reconhecimento mimético; e c) alude aos espectros, aparições e outras fantasmagorias típicas das três expressões narrativas elencadas para debate. O que acabamos por reunir no volume é um conjunto bastante variado de posições argumentativas debruçadas sobre alguns objetos já consagrados, e outros pouco conhecidos do público.

Em O modo fantástico em "O Hobbit" - (re)fluxos cinema/ literatura os autores Vítor Castelões Gama, Werbson dos Santos Silva e Wiliam Alves Biserra se debruçam sobre aspectos comparativos entre a icônica obra de J. R. R. Tolkien e a dirigida por Peter Jackson, mensurando os aspectos fantásticos em ambas as criações.

De autoria de Maria da Luz Alves Pereira, "Metzengerstein" de Poe na grande tela faz uma leitura das opções fantásticas convocadas 
pela adaptação realizada pelo diretor Roger Vadim para o antológico conto de Edgar Allan Poe - média-metragem que integra o projeto audiovisual Histórias extraordinárias (Histoires extraordinaires, 1968), em companhia de Federico Fellini e Louis Malle.

"O cerro dos enforcados" (1954), de Fernando Garcia: um filme fantástico?, escrito por Jean Carlos Carniel Luciene em coautoria com Marie Pavanelo, problematiza a natureza do filme português que dá título ao artigo, uma adaptação cinematográfica do conto $O$ defunto, de Eça de Queirós.

Vinicius Lucas de Souza e Aparecido Donizete Rossi abordam em seu artigo Nós somos John Malkovich a presença do inquietante freudiano no filme Quero Ser John Malkovich, o qual se articula a partir do duplo que, de acordo com a tese defendida pelos autores, torna-se múltiplo.

0 artigo $O$ real e seus truques: o efeito fantástico em "The prestige", de Christopher Nolan convoca o universo da prestidigitação para explorar as fronteiras do real e do ilusório, algo que recebe uma dimensão sobrenatural ou um efeito fantástico no ato mágico da cena. Roteirizado por Christopher Nolan e Jonathan Nolan, o filme é a versão cinematográfica do romance The prestige, do britânico Christopher Priest.

Poe's biopics: representations of the author in D.W. Griffith's Edgar Allen Poe and James McTeigue's The Raven, de Amanda Leonardi de Oliveira e Elaine Indrusiak, debate a cinebiografia do célebre contista e poeta estadunidense, cuja vida e obra são objeto de três artigos neste número da revista, o que evidencia a importância e a multiplicidade da obra de Poe para o gótico, o insólito e o fantástico. 
Projeto textual de Fabrício Basílio Pacheco da Silva e Maurício de Bragança, Imagens sussurrantes: cinema de fluxo e tempo mítico em "Histórias que só existem quando lembradas" enfoca a coprodução entre Brasil, Argentina e França, capitaneada pela diretora Júlia Murat. $\mathrm{O}$ enfoque desta vez recai na confluência entre registro, tempo e memória, algo que toma como aparato "fantástico" o dispositivo fotográfico, muito especialmente as pinholes da protagonista do filme, a mochileira Rita.

Em "Miguel Miguel": o fantástico traduzido para o cinema, Wellingson Valente dos Reis, José Guilherme de Oliveira Castro e Lucilinda Ribeiro Teixeira apostam nas bases teóricas da intermidialidade, intersemiótica e intertextualidade para analisar o processo de tradução da obra de cunho fantástico Miguel Miguel, de Haroldo Maranhão, para o filme homônimo dirigido por Roger Elarrat.

Jayme Soares Chaves, autor de Cinema retrofuturista $e$ steampunk: possiveis origens de um subgênero literário, propõe interessantes viagens no tempo ao articular presentes, passados e futuros em sua análise do steampunk, variante do cyberpunk cujo ápice se deu entre as décadas de 1980 e 1990.

A queda das casas de Edgar Allan Poe e de Roger Corman na literatura e no cinema b-side, de Auricélio Soares Fernandes e Luiz Antonio Mousinho Magalhães, retoma um dos mais célebres contos de Poe através da versão dirigida por Roger Corman em 1960, cujo título em português é $O$ Solar Maldito.

A seção de resenhas conta com textos que enfocam quatro obras publicadas em 2017. São elas: Cartografias para a ficção 
científica mundial cinema e literatura (organizado por Alfredo Suppia), David Lynch, multiartista (organizado por Daniel Serravalle de Sá e Marcio Markendorf), Historia de lo fantástico en la cultura española contemporánea (1900-2015), de autoria de David Roas, e $O$ fantástico: procedimentos de construção narrativa em $H$. $P$. Lovecraft, de Filipe Furtado.

O número 6 da Abusões também traz uma seção inédita, chamada Tradução e diálogo. A tradução está presente em $O$ fantástico no cinema. Sonhos e medos do terceiro milênio, artigo oriundo de conferência proferida em 2005 por Irène Bessière e traduzido para o espanhol por Marcela Santero. Tal versão originou a tradução em português aqui publicada, de autoria de Flavio García e Ana Cristina dos Santos. Já o artigo de Claudio Vescia Zanini, intitulado $O$ horror no cinema do terceiro milênio: um diálogo com Irène Bessière, retoma o texto da francesa através de conexões, olhares diversos, concordâncias e discordâncias, além de uma necessária atualização do corpus de análise.

Esperamos que este número da revista Abusões contribua para o crescimento da discussão e para o desenvolvimento de novas e necessárias reflexões acerca do insólito, do fantástico e do gótico. 